\title{
Tackling Modern Slavery, the Ugliest Phenomenon of Our Times: An Invita- tion to the IB Scholarly Community
}

\author{
Snejina Michailova, The University of Auckland Business School, New Zealand \\ Christina Stringer, The University of Auckland Business School, New Zealand
}

\section{A Sad Foreword}

Some of you, as you begin reading this piece, will have your iPhone near you. An essential part of an iPhone battery is the mineral cobalt, which is mined by "workers" from the Democratic Republic of Congo. The quotation marks are not accidental - would you call people who scrape and sift mud for over 12 hours a day, for just \$1-2 a day, "workers"? We call them slaves. These slaves, some as young as 7 years old, work in intense heat without any protective gear. They have no shelter on the exposed mountain tops, are often beaten by security guards, and are forced to pay "fines" by police and other officials. Congo Dongfang Mining International, a wholly owned subsidiary of Zhejiang Huayou Ltd. (ZHL), is the largest buyer of cobalt in the area. ZHL supplies multinational corporations (MNCs) such as Apple, Microsoft, and Samsung. According to Amnesty International and African Research Watch (Afrewatch) in their 2016 report entitled "This is What We Die For" none of the MNCs could fully verify where the cobalt in their products comes from because of the complex nature of the supply chain.

"Workers" in Bangladesh make school uniforms and clothes for Tesco, Asda, Aldi, and other MNCs. Many workers are, in fact, slaves - again, how else would one describe people who work 12-hour shifts, about 74 hours a week, and are paid only 25 pence (\$0.36) an hour? They live in abject conditions. Aldi has committed to a full investigation into the allegations. A Tesco spokeswoman stated: "We work closely with our suppliers to ensure good working conditions and we know they pay above market averages. We will continue to work with suppliers to improve wages and would take firm action against any kind of abuse or under-payment" (cited in Bright, 2017).

Maybe you are now thinking: There is a lot to improve in developing countries.... Indeed. But please consider just the following three facts: The USA is a destination country for forced labor in, for example, the hospitality, manufacturing, and healthcare industries. In 2016, New Zealand had its first human trafficking conviction, which pertained to the exploitation of migrant workers. The UK and Italy are among countries beset with claims of the exploitation of migrant workers in their agricultural sectors supplying MNCs. The list can go on and on. Developed countries are not immune to modern slavery. Sadly, it is a widespread crime and an international business (IB).

\section{Modern Slavery and IB"s Scholarly Silence}

Modern slavery is an umbrella term that includes slavery and slavery-like practices, forced labor, bonded labor, involuntary servitude, human trafficking, and other forms of exploitation (ILO, Walk Free Foundation \& IOM, 2017). While there is no legal definition of the term, there are legal instruments which define (and prohibit) the main forms of exploitation. Modern slavery is founded on the commodification and dehumanization of labor-people are forced to work under the threat of violence, for little or no pay, and are treated as a commodity by their employer, with restrictions placed on their freedom of movement. The economic benefits obtained through such exploitation is a key reason why slavery continues to flourish. While the legal ownership of a slave is prohibited under international law, enslavement can be contractual in nature, with the exploiter controlling the individual through, for example, physical and psychological means.

Modern slavery is one of the most, if not the most, extreme form of injustice and an abhorrent crime against humanity. It is a profitable IB which exists and thrives on an unprecedented scale. In 2016 there were in the vicinity of 40.3 million 
slaves worldwide, of whom 16 million were victims of forced labor in the private economy (as distinguished from forced sexual exploitation and state-imposed labor) (ILO et al., 2017). An estimated US $\$ 150$ billion annual profit is obtained from forced labor (ILO, 2016). Slavery operates in a hidden form in the complex and increasingly fragmented supply chains of MNCs linking supplier firms, labor contractors, and global retailers. While slavery has existed for centuries, the globalization of production has contributed substantially to it becoming modern and refined, and practiced more extensively than ever across borders.

IB research remains largely silent on the topic of modern slavery. We are not aware of research published in IB journals mainstream or otherwise - on modern slavery. In the 112-page AIB 2017 annual conference program there was not one mention of "slavery" or related terms. Despite the numerous plenary sessions on "important topics in IB research" and a number of published articles on "big questions," "grand challenges," etc., our collective silence regarding modern slavery is deafening. We are behind the media, many MNCs, and policymakers that actively discuss (and act on) the issue. We are also behind other disciplines, such as Development Studies, Law, Sociology, and Human Geography that have tackled the topic for some time. We also seem to be slower than our Management colleagues, who have joined others in addressing the phenomenon of modern slavery. In contrast, we seem to be doing a poor job of influencing discussions that really matter in our world.

This article offers an invitation to fellow IB scholars to start a conversation on modern slavery in IB or as an IB. As an initial step, we open the conversation with a brief sketch of only a few selected issues. We portray modern slavery as a persistent and thriving $\mathrm{IB}$, a business that operates across borders and persists in MNCs' supply chains. We then look at the IB of modern slavery through the lens of one of the most utilized theories in IB research, institutional theory. We intentionally pose more questions than answers, with the hope that others will join the overdue discussion. We also suggest promising avenues in IB scholarship for studying modern slavery.

\section{A (Very Brief) Explanation of Modern Slavery through the Lens of Institu- tionall Theory}

Modern slavery as an IB phenomenon can be analyzed with the help of multiple theoretical tools. Here we briefly delineate just one possibility, namely institutional theory. Old institutionalism, in particular, offers a fertile analytical prism in terms of at least two ideas-the inherent complexity of institutions, and institutional deflection - that help us understand why modern slavery exists in many MNCs and their supply chains.
The institutional pressures that MNCs face are becoming ever more diverse and increasingly weaker, partly because globalization has led to disconnects between transnational institutions and national institutional arrangements. Old institutionalism emphasizes that complexities, ambiguities, and contradictions are inherent to the existence of institutions. Thus, not only do MNCs play around with institutional rules and requirements, but they can also deliberately manipulate those. Put bluntly, MNCs are not only capable of changing the rules of the game; they can change the game itself and introduce new games. For them, it is no longer about "taking what the system gives" (Fligstein, 1997: 399); it is rather about establishing systems that they can benefit most from. And slavery can be a highly profitable business.

When an institutional environment is highly complex and diverse, it is more prone to cracks and contradictions. The capability of MNCs to use these cracks and contradictions skillfully to serve a particular self-interest is considerable. Companies can develop what Crane (2013: 58) calls "slavery management capabilities." These are "exploiting/insulating" and "sustaining/ shaping" capabilities that allow firms to engage in institutional deflection, a process which Crane (2013: 51) defines as one where "the institutional forces that render slavery illegitimate are deflected in some way by external and internal contingencies." By exploiting and insulating capabilities—such as debt management, accounting opacity, and supply chain management-firms are able to take advantage of their external contexts. The sustaining and shaping capabilities that allow a firm to avoid or deflect pressure to conform to legitimate labor practices include their moral legitimization (their justification for using slaves) and their domain maintenance, whereby they will, for example, bribe officials in order to reduce regulatory oversight. These practices are facilitated by the fact that victims of slavery are often isolated and in a controlled environment such as onboard fishing vessels or in sweatshops. Their isolation is often perpetuated by the lack of communication among the multiple layers within the supply chain, thus reducing the opportunity for community norms to be imposed.

Because the multiple institutional contexts in which MNCs operate are fragmented and continuously changing, the interface between the MNC and institutions is inherently flexible and dynamic. What MNCs find fits them best today may be very different from what they found optimal yesterday or would deem appropriate tomorrow. This results in the MNC having extreme discretion and agency power, sufficient to deflect the power of institutions. MNC supply chains typically span multiple countries and involve several layers - not only individual companies, but entire clusters and industries. Thus, "slavery can be found in any part of the chain and in any country" (Lake et al., 2016: 6), especially in supply chains which have ubiquitous subcontracting networks. This is not to say that MNCs necessarily condone slavery in their supply chains, but to argue that when cost pressures are passed down the 
chain, subcontractors are likely to be inclined to underprice (or not pay at all for) labor.

\section{What Conversations on Modern Slav= ery Can and Should the IB Scholarly Community Address?}

Bales (2012: 235) links MNCs to modern slavery in the following unambiguous way: "Today economic links can tie the slave in the field or the brothel to the highest reaches of international corporations. How these links join up is the central mystery of the new slavery, and one that desperately needs investigation." IB scholars are very well positioned to address this and other mysteries that are at the heart of one of the most illegitimate and inhuman businesses of our time. Our collective scholarly silence on the topic of modern slavery is unjustified. We have the opportunity for studies that are both relevant and interesting from a research viewpoint, and that can be powerful in terms of triggering change in existing policies and practices. We suggest a few directions that we find promising.

The MNC will continue to be prominent in IB research as one of its central units of analysis. But we need to start looking at the MNC differently. For instance, what are the inadequacies in some of the principles that govern MNCs and their patterns of conduct that allow modern slavery to exist and per-

sist? Are MNCs powerless to control their supply chains? If so, why? How is it possible that MNCs can, to a great extent, control, manipulate and even construct, their institutional environments, but often appear to be powerless to control their supply chains that can become breeding grounds for modern slavery? How can we position the various exploitative practices, ranging from precarious working conditions (e.g., violation of contractual rights) to abusive slavery on a continuum that goes beyond semantic nuances and specifies the mechanisms associated with these practices?

If MNCs are not powerless, what can they do to prevent modern slavery in their multilayered supply chains? How can they exploit the very same cracks and contradictions in the institutional environments that allow slavery to prosper, and instead potentially destroy slavery? Some MNCs are working to address slavery in their supply chains. They are collaborating with non-government organizations (NGOs) and undertaking initiatives to ensure transparency in their supply chains. Following the identification of human rights abuses in the cobalt supply chain from the Democratic Republic of Congo, and subsequent efforts undertaken by Apple, Amnesty International considers Apple to be a leader in addressing human rights abuses in this area. In 2015, after a year-long investigation by
Verité, a fair labor NGO, Nestlé announced that slavery was occurring in its fisheries supply chain.

What can we learn from collaborative initiatives that MNCs are engaged in? This is a fantastic opportunity for us as scholars to work with, and learn from, MNCs and NGOs. Increasingly MNCs must meet transparency requirements, such as the UK's Modern Slavery Act and the California Transparency in Supply Chains Act. How are these new transparency requirements shaping the activities of MNCs? These and related questions can frame and tell a different tale about the MNC.

The role of key actors involved in modern slavery is of key interest - the exploiter (for whom slavery is a profitable business often with a huge return on their "investment"), the broker

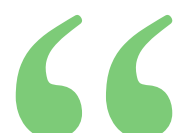

IB scholars are very well positioned to address... one of the most illegitimate and inhuman businesses of our time.

(the intermediary without whom slavery is difficult to maintain), and the victim (the vulnerable individual). The victims are most vulnerable, and maybe this is why much of extant research in other disciplines has centered on victimhood. We see merit in efforts to understand the role of slaves themselves in IB-related activities. Their unwilling (and sometimes willing) participation in their dehumanization is a fascinating puzzle. While individuals may voluntarily enter what they perceive to be a legitimate employment relationship, they can from that point onwards be trapped into slavery. They may be employed under fraudulent contracts, controlled through debt bondage as well as threats of, or actual, violence. So, what is the line between slavery and other exploitative labor relations? When are exploitative and coercive behaviors likely to occur-when people enter an employment relationship or at the point of exit where they realize they are trapped in an employment relationship they are unable to escape from? Or somewhere in between?

Research efforts also need to examine the other key "practitioners of slavery," the exploiters and the brokers, both as individual actors, and also as powerful groups of actors. They gain economic advantages from engaging in slavery despite pressures that seek to discourage engagement in the crime. What 
are their incentives and cost-benefit considerations? How do they position themselves within existing institutions so that they not only exploit present opportunities, but also create new ones? What resources do they utilize to help make slavery flourish? Do they operate only at the margins of institutions (which, in their very nature, are often ambiguous, contested, and blurred), or also at the heart of well-functioning institutions in developed countries? Such a line of inquiry can inspire significant efforts to unpack the phenomenon of modern slavery, both theoretically and empirically.

Questions that deserve research attention also relate to slavery as an institution (rather than a business). Martí and Fernández (2013: 1206) highlight that "observing situations of oppression bring to the fore a fundamental question: How is (any kind of) institutional work possible when human beings have been dehumanized?" This too is an essential question in relation to modern slavery. Seeking answers is likely to evoke related questions: What institutional mechanisms and devices allow modern slavery to exist? What institutional work makes it persist? Understanding the subordinate social structures within the complex systems of modern slavery can reveal important insights into what allows it to prosper. It could be because of cracks and faults in the institutions that modern slavery thrives; it could alternatively be because of the lack of "good administration" or because of a combination of the two. These issues are well worth investigating.

The above questions are a very modest slice of a huge opportunity in front of us as IB scholars. We can conduct research that can save lives. And so we should!

\section{References}

Bales, K. 2012. Disposable people: New slavery in the global economy. Berkeley, CA: University of California Press.

Belser, P., de Cock, M., \& Mehran, F. 2005. ILO minimum estimate of forced labour in the world. Nondiscrimination, 7.

Bright, E. 2017. Tesco, Aldi and Asda accused of paying poverty wages to Bangladeshi workers. https://www.thegrocer.co.uk/channels/ supermarkets/tesco-aldi-and-asda-accused-of-exploiting-bangladeshi-workers/557778.article. Accessed 11 April 2018.

Crane, A. 2013. Modern slavery as a management practice: Exploring the conditions and capabilities for human exploitation. Academy of Management Review, 38(1): 49-69.

Fligstein, N. 1997. Social skill and institutional theory. American Behavioral Scientist, 40: 397-405.

International Labour Organization (ILO). 2016. ILO standards on forced labour: The new protocol and recommendation at a glance. Geneva: ILO.

International Labour Organization (ILO), Walk Free Foundation, \& International Organization for Migration (IOM). 2017. Global estimates of modern slavery: Forced labour and forced marriage. Geneva: ILO.
Lake, Q., MacAllister, J., Berman, C., Gitshaw, M., \& Page, N. 2016. Corporate approaches to addressing modern slavery in supply chains: A snapshot of current practice. Ethical Trading Initiative and the Ashridge Centre for Business and Sustainability at Hult International Business School, 29.

LeBaron, G., \& Ayers, A.J. 2013. The rise of a 'new slavery'? Understanding African unfree labor through neoliberalism. Third World Quarterly, 34(5): 873-892.

Martí, I., \& Fernández, P. 2013. The institutional work of oppression and resistance: Learning from the holocaust. Organization Studies, 34(8): $1195-1223$.

Snejina Michailova (s.michailova@auckland.ac.nz) is a Professor of International Business at The University of Auckland Business School, New Zealand. She received her PhD from Copenhagen Business School, Denmark. She conducts research in the areas of International Business, Management, and Knowledge Management. She is currently Co-Editor-in-Chief of critical perspectives on international business. Her two major current research projects are on modern slavery as / in international business and on host country nationals.

Christina Stringer (c.stringer@auckland.ac.nz) is an Associate Professor in International Business at The University of Auckland Business School, New Zealand. An economic geographer by training, she conducts research on global value chains with a particular focus on labor and human rights abuses. She has recently finalized a research project on migrant worker exploitation in New Zealand and has published on slavery in New Zealand's fishing industry. 